\section{Diet and cancer in Northeast Brazil: evaluation of eating habits and food group consumption in relation to breast cancer}

\author{
Dieta e câncer no Nordeste do Brasil: avaliação da \\ relação entre alimentação e consumo de grupos \\ de alimentos e câncer de mama
}

\author{
${ }^{1}$ Faculdade Evangélica do \\ Paraná, Curitiba, Brasil. \\ 2 Faculdade de Saúde \\ Pública, Universidade de \\ São Paulo, São Paulo, Brasil. \\ ${ }_{3}$ Centro de Ciências da \\ Saúde, João Pessoa, Brasil. \\ Correspondence \\ F. E. L. Lima \\ Faculdade Evangélica do \\ Paraná. \\ Rua Castro Alves 99, apto. 10 \\ Curitiba, $P R$ \\ 80240-270, Brasil. \\ flavia_emilia@yahoo.com.br
}

\begin{abstract}
A hospital-based case-control study was performed from August 2002 to November 2003 in Northeast Brazil. Eighty-nine women were recruited with histologically confirmed breast cancer (age 30-80 years), matched for age with 94 controls. Food consumption of cases and controls was evaluated by foods and food groups, categorized in consumption tertiles. Odds ratio (OR) and 95\% confidence intervals (95\%CI) were obtained through unconditional logistic regression. Intake of fruits and juices, beans, and dairy products showed a strong association with reduced risk of breast cancer. Consumption of red and fried meat was positively associated with risk of breast cancer (red meat $-O R=4.30 ; 95 \%$ CI: 1.7410.67; $p$ for trend $=0.00$ ). No association was observed in vegetable and sausage meat groups and breast cancer. Red and fried meat may be risk factors, and intake of fruit, beans, and dairy products may protect against breast cancer.
\end{abstract}

Breast Neoplasms; Food; Diet; Food Habits
Flávia Emília Leite de Lima 1

Maria do Rosário Dias de Oliveira Latorre 2

Maria José de Carvalho Costa 3

Regina Mara Fisberg ${ }^{2}$

\section{Introduction}

The World Health Organization (WHO) has warned that from 2000 to 2020 , cancer prevalence in developing and developed countries is expected to increase by $73 \%$ and $29 \%$, respectively 1 . In Brazil, in the 1930s, cancer was the fifth among all causes of death, reaching third place by the late 1980s, while breast cancer had become the second cause of mortality in women 2,3 .

In addition to reproductive factors, which may contribute up to $30 \%$ of breast cancer cases, it is known that sedentary lifestyle together with obesity and inadequate eating habits may increase this risk by $40 \% 4$.

Mondini \& Monteiro 5, assessing the dietary pattern of the Brazilian population, also reported that the contribution of fruits to total calorie intake in Brazil decreased from 3.8\% in 1962 to $2.5 \%$ in 1988. During the 1990 s, Monteiro et al. 6 showed that there had been an increase in consumption of alcoholic beverages and foods of animal origin, while the share of fruits, greens, and other vegetables in total diet remained practically unchanged.

Dietary patterns in different regions of Brazil show specific characteristics. It is thus necessary to observe the different eating habits in different regions in order to identify potential risk factors for breast cancer accordingly. Studies on such relationships are still rare in the country. This study reports on the relationship between diet 
and food groups and risk of breast cancer among women in Northeast Brazil.

\section{Material and methods}

A hospital-based case-control study was performed in the municipality of João Pessoa, Paraíba State (Northeast Brazil) from August 2002 to November 2003. The following parameters were considered for sample size calculation: statistical significance level of $5 \%(\alpha=0.05)$, study power $(1-\beta)$ of $80 \%$, and odds ratio $(\mathrm{OR})=2.5$ for exposure prevalence among controls 7 . The sample size was calculated according to Schlesselman 8, resulting in a minimum of 170 persons ( 85 cases and 85 controls).

A total of 89 cases and 94 controls were recruited into the study from two referral hospitals in the State (age 30-80). Eligible cases included women who were newly diagnosed with primary breast cancer. Cases were interviewed after diagnosis and before initiating treatment. Patients who had recurrent breast cancer, adjuvant therapy (radiotherapy or chemotherapy) prior to surgery, or a history of previous cancer were excluded from the study. No cases refused to participate in the study.

For each case, a control was selected (matched by age \pm 5 years) from the various outpatient clinics in one of the selected referral hospitals. Controls were selected randomly from the cardiology, rheumatology, internal medicine, psychology, gastroenterology, gynecology, ophthalmology, and ear, nose, and throat outpatient clinics. The main diagnosis of the controls included ocular problems (23\%), rheumatologic disorders (45\%), orthopedic disorders (20\%), and other diagnoses in smaller proportions. Patients with a history or suspicion of breast cancer at the time of interview or who had any disease that was positively or negatively associated with the target exposure were excluded from the study.

One hundred and five potential controls were eligible to participate, but 5 (4.8\%) refused to participate, 3 (2.8\%) had type- 1 diabetes, and 3 (2.8\%) had chronic renal disorders. The questionnaire developed for the present study was applied by an interviewer in a face-to-face interview. Questions were asked on socio-demographic factors (schooling, marital status, place of birth), reproductive factors (age at menarche, parity, number of live births, age at first birth, contraceptive use, hormone replacement therapy, and age at menopause), family history of cancer, nutritional status, and physical activity. Nutritional status was assessed during the interview by weight and height to calculate body mass index (BMI), us- ing the WHO classification ${ }^{9}$. Physical activity was defined as exercise at least twice a week for 30 minutes or more 10 .

Written consent was obtained from cases and controls. The study was approved by the Research Ethics Board, Faculdade de Saúde Pública, Universidade de São Paulo [School of Public Health, University of Sao Paulo, Brazil].

\section{Food frequency questionnaire}

A Quantitative Food Frequency Questionnaire (QFFQ) was developed and validated for the present study. Development of this questionnaire has already been published 11. Briefly, a food list was obtained through 24-hour recall (R24h) applied to 100 women (25-79 years of age), clients of public health services. The QFFQ list contained 68 food items, and study subjects were asked to report their frequency of consumption (by day, week, month, or year), and portion size of each food item consumed, over the one-year period preceding confirmation of disease (or over the year preceding the interview date, for the controls). The information was collected in a faceto-face interview performed at the hospital by a trained interviewer. Relative validity was assessed by comparing four 24-hour recalls and QFFQ. Between four to six weeks after the first personal contact, the first 24-hour recall was applied by telephone. No interview was scheduled in advance. 24-hour recall was repeated at three-month intervals on non-consecutive days, including weekdays and weekends and seasonal food items. Pearson de-attenuated correlation coefficients ranged from 0.36 for vitamin $\mathrm{C}$ to 0.67 for carbohydrates, with 0.64 for energy and 0.68 for vitamin A.

To analyze the food groups, the 68 items were regrouped according to their similarities in nutritional value. The a priori approach was utilized, namely: cereals, roots, and tubers, breads and biscuits, dairy foods, vegetables, fruits and juices, oils and fats, sugars and sweets, coffee and soft drinks, red meat, sausage meat and offal, white meat, cooked meat, fried meat, eggs, and beans.

All the estimates for food groups were calculated using the nutritional analysis software Dietsys 4.012 . This software contains information on food compositions provided by the United States Department of Agriculture (USDA). For additional Brazilian regional food, tables of food composition were utilized as references 13,14. The intake frequencies for some fruits were adjusted for seasonality. 


\section{Statistical analysis}

To evaluate the relationship between the sociodemographic, reproductive, and anthropometric variables and cancer, the chi-squared test with Yates correction was utilized. The significance level was set at $\alpha=0.05$. Since the number of cases and controls of pre-menopausal age were small, the analyses performed did not stratify the women by this variable. Nutritional intakes were categorized into tertiles according to the population distribution in the control group. Nutrients were adjusted for energy by the "residual method" proposed by Willett \& Stampfer 15. Estimated risk associated with consumption of nutrients and food groups was evaluated by OR and unconditional multiple logistic regression models, adjusted for confounding variables 16 .

The matching variable for the study, i.e. age 17 , was used in the statistical modeling. Control variables with $\mathrm{p}$-values (descriptive significance level of the test) less than or equal to 0.20 in the univariate analysis were selected for the multiple logistic regression models.

Dose-response effect was tested using Mantel-Haenszel chi-squared test for linear trends, using the ordinal tertiles of nutrient intake. All the analyses were performed using the SPSS 10.0 software (SPSS Inc., Chicago, USA).

\section{Results}

Mean age of subjects was 56 years, with a mean of $6.6 \pm 4.8$ years of schooling. Sedentary lifestyle was predominant in both groups, and mean BMI was $24.86 \mathrm{~kg} / \mathrm{m}^{2}$. Some $52 \%$ of cases and $48 \%$ of controls had normal weight. Table 1 shows the distribution of cases and controls according to reproductive variables. For both groups, age at menarche was mostly between 12 and 15 years. The two groups had similar numbers of children. Most women were less than 25 years old when their first child was born $(71.9 \%$ of cases and $66 \%$ of controls) and had not used oral contraceptives. Age at menopause was statistically different between groups ( $p<0.01)$, with more cases $(43.8 \%$ vs. $31.9 \%$ of controls) reaching menopause before 50 years of age.

Table 2 shows average weekly intakes of food groups between cases and controls. Cereals, roots and tubers, breads and biscuits, and fruits and juices were the primary food groups in the diet. According to the non-parametric test to verify mean differences between groups, bread, meat, and egg intake was statistically different between cases and controls.
Intake of dairy foods, beans, and eggs was significantly associated with reduced risk of breast cancer. The group of fruits and juices and beans also displayed a strong association with reduced risk of breast cancer. Vegetable consumption was shown to protect against breast cancer in the intermediary tertile of intake, after adjusting for energy (Table 3 ).

Red meat and fried meat were positively associated with risk of breast cancer (red meat $-\mathrm{OR}=$ 4.30; 95\%CI: $1.74-10.67, \mathrm{p}$ for trend $=0.00$; fried meat - OR for $>7$ portions/week vs. $\leq 2.8$ portions $/$ week $=4.69$; $95 \%$ CI: $1.29-17.06$; $\mathrm{p}$ for trend $=$ 0.03). No significant association was observed between sausage consumption and breast cancer risk.

\section{Discussion}

This study shows that cereals, roots and tubers, and breads and biscuits were the primary food groups eaten by subjects, followed by fruits and juices, vegetables, and coffee and soft drinks among cases, and fruits, meats, and vegetables among controls. Rivera \& Rivera 18 , in an analysis of the diversity of diet in Northeast Brazil, found that the food staple in this region is carbohydrate (e.g., rice, yam, and manioc flour).

It is important to highlight the consumption of beans. The strong association between beans and reduced risk of breast cancer deserves in-depth consideration. According to a recent family budget survey in Brazil, although overall consumption of beans and other leguminous vegetables had decreased, the State of Paraíba is the largest consumer of this food group in the country, with a relative share of $11.96 \%$ of total energy for this group 19. Beans are a staple food, i.e., they are part of the highly heterogeneous dietary habits of the Brazilian people, as demonstrated in a multi-center study by Galeazzi et al. 20. A study by Marchioni et al. 21 in Southeast Brazil showed that the traditional dietary pattern consisting of rice, beans, and meat was associated with reduced oral cancer.

For intake of fruits and juices, a significant dose-response effect can be seen in relation to risk of breast cancer (Table 2). This result agrees with several other studies $22,23,24$. In contrast, reviews by Gandini et al. 25 and Riboli \& Norat 26 showed a protective relationship for vegetables, but not for fruits. Furthermore, other studies have shown no association for either group 27,28.

According to the World Cancer Research Fund (WCRF) 29, fruits and vegetables, particularly green vegetables, are probably associated with reduced breast cancer. However, in the United 
General characteristics of the study population. João Pessoa, Paraíba State, Brazil, 2002-2003.

\begin{tabular}{|c|c|c|c|c|c|}
\hline \multirow[t]{2}{*}{ Variable } & \multicolumn{2}{|c|}{$\begin{array}{l}\text { Cases } \\
(\mathrm{n}=89)\end{array}$} & \multicolumn{2}{|c|}{$\begin{array}{l}\text { Controls } \\
(n=94)\end{array}$} & \multirow[t]{2}{*}{$\mathbf{p}$} \\
\hline & $\mathbf{n}$ & $\%$ & $\mathbf{n}$ & $\%$ & \\
\hline \multicolumn{6}{|c|}{ Age at menarche (years) * } \\
\hline$<12$ & 21 & 23.6 & 15 & 16.0 & \\
\hline $12-15$ & 55 & 61.8 & 68 & 72.3 & \\
\hline$\geq 15$ & 9 & 10.1 & 8 & 8.5 & 0.486 \\
\hline \multicolumn{6}{|l|}{ Parity } \\
\hline Nulliparous & 14 & 15.7 & 14 & 14.9 & \\
\hline 1-3 children & 37 & 41.6 & 37 & 39.4 & \\
\hline$\geq 4$ children & 43 & 42.7 & 43 & 45.7 & 0.917 \\
\hline \multicolumn{6}{|c|}{ Age at first childbirth } \\
\hline No children & 14 & 15.7 & 14 & 16.0 & \\
\hline$<25$ years & 64 & 71.9 & 62 & 66.0 & \\
\hline$>25$ years & 11 & 12.4 & 18 & 18.0 & 0.544 \\
\hline \multicolumn{6}{|c|}{ Oral contraceptives } \\
\hline Yes & 31 & 34.8 & 22 & 23.4 & \\
\hline No & 58 & 65.2 & 72 & 76.6 & 0.123 \\
\hline \multicolumn{6}{|c|}{ Age at menopause ** } \\
\hline$<50$ & 39 & 43.8 & 30 & 31.9 & \\
\hline$\geq 50$ & 16 & 18.0 & 35 & 37.2 & 0.006 \\
\hline \multicolumn{6}{|c|}{ Family history of cancer } \\
\hline Yes & 47 & 52.8 & 54 & 58.1 & \\
\hline No & 42 & 47.2 & 39 & 41.9 & 0.572 \\
\hline \multicolumn{6}{|l|}{ Physical activity } \\
\hline Yes & 32 & 36.0 & 30 & 31.9 & \\
\hline No & 57 & 64.0 & 64 & 68.1 & 0.544 \\
\hline \multicolumn{6}{|c|}{ 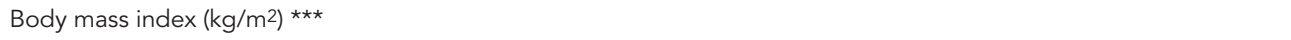 } \\
\hline Normal & 33 & 51.6 & 32 & 47.8 & \\
\hline Overweight & 17 & 26.6 & 28 & 41.8 & \\
\hline Obese & 14 & 21.9 & 7 & 10.4 & 0.083 \\
\hline
\end{tabular}

* Information not available for 4 cases and 3 controls;

** 34 cases and 43 controls were premenopausal;

*** Information not available for 23 cases and 27 controls.

Kingdom, the Chief Medical Officer's Committee on Medical Aspects of Food and Nutrition Policy (COMA) concluded that the effect was moderately consistent for vegetables but presented weak consistency for fruits 26 .

In a cohort study published recently, van Gils et al. 30 did not find any association between fruit and vegetables and breast cancer. However, they did not rule out the possibility of a protective effect by specific types of fruits and vegetables.

The present results for fruits reflect particular features of diet in Northeast Brazil. In the food frequency questionnaire constructed for the study, the majority of fruits investigated are tropical fruits such as pineapple, mango, West In- dian cherry, and cashew. In the State of Paraíba, the availability of some fruits allows greater consumption, especially in the form of juices. Vegetables like carrots, beets, and cucumber are predominant, whereas green and leafy vegetables (like broccoli, water cress, and endive), which are mainly cited in studies on diet and cancer around the world, did not appear in the present QFFQ since they are not part of the local diet. Tropical fruit intake and breast cancer risk have not been specifically studied in Brazil, and further studies are needed to confirm this relationship.

Intake of high-protein foods, particularly red meat, has been associated with increased breast cancer incidence in the last decade. The effect 
Weekly frequency distribution of food group intake among cases and controls. João Pessoa, Paraíba State, Brazil, $2002-2003$.

\begin{tabular}{lccc}
\hline Food group & \multicolumn{2}{c}{ Mean (SD) } & p * \\
& $\begin{array}{c}\text { Cases }(\mathbf{n}=89) \\
\text { portions/week }\end{array}$ & $\begin{array}{c}\text { Controls }(\mathbf{n}=94) \\
\text { portions/week }\end{array}$ \\
& & $20.80(10.08)$ & 0.71 \\
Cereals, roots, and tubers & $20.23(7.44)$ & $13.20(7.34)$ & 0.00 \\
Breads and biscuits & $17.40(9.84)$ & $18.10(6.00)$ & 0.76 \\
Fruits and juices & $19.50(10.60)$ & $15.9(10.10)$ & 0.40 \\
Vegetables & $17.90(11.30)$ & $13.00(6.20)$ & 0.09 \\
Coffee and soft drinks & $17.40(14.70)$ & $12.30(5.30)$ & 0.46 \\
Dairy products & $13.30(11.10)$ & $2.38(1.35)$ & 0.00 \\
White meat & $5.76(4.42)$ & $4.12(2.33)$ & 0.00 \\
Red meat & $7.80(5.55)$ & $3.45(2.62)$ & 0.00 \\
Sausage meat and offal & $1.10(2.20)$ & $5.13(2.64)$ & 0.00 \\
Boiled and grilled meat & $6.15(3.46)$ & $4.59(2.75)$ & 0.03 \\
Fried meat & $6.23(4.67)$ & & \\
\hline
\end{tabular}

of red meat as a promoter of breast cancer is attributed to its nutritional composition. It is rich in saturated fat and is a source of animal protein. Processed meats contain potential carcinogenic agents like heterocyclic amines, aromatic hydrocarbons, and nitrous compounds 29,31.

This information is relevant when the results in Table 3 are observed. Paraíba State shows high consumption of processed meats, which contain $\mathrm{N}$-nitroso compounds and are generally eaten fried. These meats may contribute significantly to increased risk of breast cancer, considering that they are included in the "red meat" and "fried meat" groups evaluated here.

Different hypotheses have suggested that consumption of dairy products can be classified both as a risk factor and protection against breast cancer. The main hypothesis concerning increased risk suggests that high consumption of dairy products may imply high consumption of saturated fat, and that such products may contain carcinogenic contaminants like pesticides. On the other hand, it has been suggested that dairy products have a protective effect due to the properties of calcium, which acts as a cofactor in several cellular mechanisms, including cell proliferation and differentiation 32

The latter is consistent with other studies, indicating that consuming dairy products twice a day is strongly correlated with protection against breast cancer $(\mathrm{OR}=0.04$; 95\%CI: 0.01-0.15) 24,33,34. A Uruguayan study highlighted a protective effect from low-fat fermented dairy products 35 . Cho et al. 36 , in a cohort study, found increased risk related to high-fat dairy products.
The present study sought to minimize the potential bias inherent to case-control studies. When diet and cancer are investigated, a retrospective approach to dietary habits needs to be undertaken cautiously, since current health status may substantially affect the accuracy of reporting on diet prior to diagnosis 37,38 .

Recall bias may affect the precision of data on diet and is more prevalent in case-control studies than in cohorts. In case-control studies, cases may recall their previous exposure differently from controls, since they are more motivated to participate and identify the cause of their disease 39 . Collection of data after diagnosis increases the likelihood of information bias, since dietary changes often occur after diagnosing a disease. We cannot confirm that information bias did not occur, but it was minimized by the fact that data were collected inside the hospital, in similar conditions for cases and controls.

Case selection occurred shortly after diagnosis, suggesting lack of information modification in their retrospective diet reporting. Nearly all the participants were interviewed within one month after their breast cancer diagnosis. Individuals on adjuvant therapy (e.g., radiotherapy or chemotherapy) were excluded from the sample. Care in the choice of the control group (selection of controls in the same hospital as cases, and a high responses rate) helped minimize selection bias. Controls whose disease involved long-term diet modification were excluded. Nevertheless, women with healthier lifestyles may be more likely to volunteer for epidemiological studies. 
Effect of selected food and foods group intake on breast cancer.

\begin{tabular}{|c|c|c|c|c|c|}
\hline Groups/Portions/Week & $\begin{array}{c}\text { Cases }(n=89) \\
(n=89)\end{array}$ & $\begin{array}{c}\text { Controls }(n=94) \\
(n=94)\end{array}$ & $\begin{array}{l}\text { OR crude } \\
(95 \% \mathrm{Cl})\end{array}$ & $\begin{array}{l}\text { OR adjusted * } \\
\qquad(95 \% \mathrm{Cl})\end{array}$ & $\mathrm{p}$ trend $* *$ \\
\hline \multicolumn{6}{|l|}{ Cereals, roots, and tubers } \\
\hline$\leq 14.7$ & 27 & 36 & $1.00 * \star \star$ & $1.00 * \star \star$ & \\
\hline $14.8-23.29$ & 35 & 27 & $1.73(0.85-3.51)$ & $2.13(0.77-5.90)$ & 0.66 \\
\hline$>23.29$ & 37 & 31 & $1.16(0.57-2.38)$ & $1.09(0.37-3.18)$ & \\
\hline \multicolumn{6}{|l|}{ Breads and biscuits } \\
\hline$\leq 9.1$ & 31 & 27 & $1.00 * \star \star$ & $1.00 * \star \star$ & \\
\hline $9.2-14.7$ & 28 & 37 & $0.66(0.32-1.34)$ & $0.41(0.14-1.19)$ & 0.71 \\
\hline$>14.7$ & 30 & 30 & $0.87(0.42-1.79)$ & $0.60(0.20-1.81)$ & \\
\hline \multicolumn{6}{|l|}{ Dairy products } \\
\hline$\leq 9.1$ & 49 & 12 & 1.00 *** & $1.00 * \star \star$ & \\
\hline $9.2-14.2$ & 29 & 33 & $0.21(0.10-0.48)$ & $0.27(0.10-0.75)$ & 0.00 \\
\hline$>14.2$ & 11 & 49 & $0.05(0.02-0.14)$ & $0.04(0.01-0.15)$ & \\
\hline \multicolumn{6}{|l|}{ Vegetables } \\
\hline$\leq 11.2$ & 27 & 29 & $1.00 \star \star \star$ & $1.00 * \star \star$ & \\
\hline $11.3-20.3$ & 27 & 36 & $0.81(0.38-1.74)$ & $0.31(0.11-0.83)$ & 0.45 \\
\hline$>20.3$ & 35 & 29 & $1.27(0.59-2.74)$ & $1.37(0.48-3.95)$ & \\
\hline \multicolumn{6}{|l|}{ Fruits and juices } \\
\hline$\leq 14.7$ & 51 & 9 & $1.00 * \star \star$ & $1.00 * \star \star$ & \\
\hline $14.8-21.7$ & 29 & 36 & $0.14(0.06-0.34)$ & $0.12(0.04-0.41)$ & 0.00 \\
\hline$>21.7$ & 9 & 49 & $0.03(0.01-0.08)$ & $0.02(0.01-0.12)$ & \\
\hline \multicolumn{6}{|l|}{ Eggs } \\
\hline$\leq 2.8$ & 54 & 6 & $1.00 * \star \star$ & $1.00 * \star \star$ & \\
\hline $2.9-7.0$ & 24 & 20 & $0.13(0.05-0.37)$ & $0.23(0.09-0.59)$ & 0.00 \\
\hline$>7.0$ & 11 & 68 & $0.02(0.00-0.05)$ & $0.02(0.00-0.08)$ & \\
\hline \multicolumn{6}{|l|}{ Beans } \\
\hline$\leq 6.3$ & 42 & 18 & $1.00 * \star \star$ & $1.00 * \star \star$ & \\
\hline $6.4-7.0$ & 39 & 66 & $0.25(0.13-0.50)$ & $0.23(0.09-0.59)$ & 0.00 \\
\hline$>7.0$ & 8 & 10 & $0.34(0.12-1.01)$ & $0.17(0.03-0.92)$ & \\
\hline
\end{tabular}

* Adjusted for age group, origin, oral contraceptives, age at menopause, body mass index, and energy;

** Mantel-Haenszel chi-squared test for trend;

$\star \star \star$ Reference value.

The current study has some limitations that are inherent to retrospective evaluation of food consumption. Efforts were made to minimize measurement errors within the QFFQ by appropriately structuring the questionnaire. The QFFQ allowed responses on frequencies and portion sizes of food items, as proposed by Block et al. 40 . The tendency of participants to underestimate or overestimate their portions was also corrected by adjusting for energy intake 41 .
Since this study was developed in Northeast Brazil, the results cannot be reasonably extrapolated to the entire country, considering the heterogeneity of dietary habits in Brazil's five regions. Multi-center studies are needed to further elucidate the potential effects of foods and dietary habits on breast cancer risk. 
Table 4

Effect of meat intake on breast cancer.

\begin{tabular}{|c|c|c|c|c|c|}
\hline Groups/Portions/Week & $\begin{array}{c}\text { Cases }(n=89) \\
(n=89)\end{array}$ & $\begin{array}{l}\text { Controls }(n=94) \\
\qquad(n=94)\end{array}$ & $\begin{array}{l}\text { OR }_{\text {crude }} \\
(95 \% \mathrm{Cl})\end{array}$ & $\begin{array}{l}\text { OR adjusted } \\
\qquad(95 \% \mathrm{Cl})\end{array}$ & $p$ trend $* *$ \\
\hline \multicolumn{6}{|l|}{ Red meat } \\
\hline$<7$ & 29 & 60 & $1.00 * \star \star$ & $1.00 * \star \star$ & 0.00 \\
\hline$\geq 7$ & 60 & 34 & $3.65(1.98-6.73)$ & $4.30(1.74-10.67)$ & \\
\hline \multicolumn{6}{|l|}{ White meat } \\
\hline$<7$ & 42 & 54 & $1.00 * \star \star$ & $1.00 * \star \star$ & \\
\hline$\geq 7$ & 47 & 40 & $1.51(0.84-2.71)$ & $2.40(0.97-5.92)$ & 0.17 \\
\hline \multicolumn{6}{|l|}{ Sausage meat and offal } \\
\hline$\leq 2.1$ & 71 & 79 & $1.00 * \star \star$ & $1.00 * \star \star$ & \\
\hline $2.2-4.2$ & 16 & 9 & $1.98(0.82-4.76)$ & $2.00(0.47-8.51)$ & 0.99 \\
\hline$>4.2$ & 2 & 6 & $0.37(0.07-1.90)$ & $0.99(0.11-8.83)$ & \\
\hline \multicolumn{6}{|l|}{ Boiled } \\
\hline$\leq 4.0$ & 42 & 40 & $1.00 * \star \star$ & $1.00 * \star \star$ & \\
\hline$>4.0$ & 47 & 47 & $0.83(0.46-1.49)$ & $1.36(0.58-3.15)$ & 0.53 \\
\hline \multicolumn{6}{|l|}{ Fried } \\
\hline$\leq 2.8$ & 22 & 22 & $1.00 * \star \star$ & $1.00 * \star \star$ & \\
\hline
\end{tabular}

* Adjusted for age group, origin, oral contraceptives, age at menopause, body mass index, and energy;

** Mantel-Haenszel chi-squared test for trend;

$\star \star \star$ Reference value.

\section{Resumo}

Realizou-se um estudo do tipo caso-controle de base hospitalar no Município de João Pessoa, Paraíba, Brasil. Participaram 183 indivíduos (89 casos e 94 controles) na faixa etária entre 30 e 80 anos, com pareamento por idade. O consumo alimentar de casos e controles foi avaliado por alimentos e grupos de alimentos categorizados em tercis de consumo. A estimativa dos valores da odds ratio (OR) e intervalos de confiança de 95\% (IC95\%) foi realizada por regressão logística múltipla não-condicional. O consumo de frutas e sucos, feijão e leite e derivados apresentou uma forte associação com a redução no risco de câncer de mama. O consumo de carnes vermelhas e de carnes fritas esteve positivamente associado ao risco de câncer de mama (carne vermelha - OR = 4.30; IC95\%: 1,74-10,67; $p=0,00$ ). Não foi observada associação entre o consumo dos grupos de vegetais e embutidos com o câncer de mama. Carne vermelha e carnes fritas podem ser fatores de risco, e o consumo de frutas, feijão e leite e derivados pode atuar como protetor do câncer de mama.

Neoplasias Mamárias; Alimentos; Dieta; Hábitos Alimentares

\section{Contributors}

F. E. L. Lima was the study's principal investigator. F. E. L. Lima and R. M. Fisberg designed the study and conducted the statistical analyses of all the data. M. J. C. Costa participated in the data acquisition. M. R. D. O. Latorre, F. E. L. Lima, and R. M. Fisberg participated in data interpretation for all the research activities. None of the authors had any financial or personal interest in agencies funding this study.

\section{Acknowledgements}

The authors wish to thank the Conselho Nacional de Desenvolvimento Científico e Tecnológico [CNPq, Brazilian National Research Council] for grant no. 475215/01-0. 


\section{References}

1. World Health Organization. Diet, nutrition and the prevention of chronic diseases. Geneva: World Health Organization; 2003. (Technical Report Series, 916).

2. Mendonça GAS. Câncer no Brasil: um risco crescente. Rev Bras Câncer 1992; 38:167-76.

3. Instituto Nacional de Câncer. Estimativa da incidência e mortalidade por câncer no Brasil em 2003. Rio de Janeiro: Instituto Nacional de Câncer; 2003.

4. McTiernan A. Behavioral risk factors in breast cancer: can risk be modified? Oncologist 2003; 8:326-34.

5. Mondini L, Monteiro CA. Mudanças no padrão de alimentação da população urbana brasileira (1962-1988). Rev Saúde Pública 1994; 28:433-9.

6. Monteiro CA, Mondini L, Costa RBL. Mudanças na composição e adequação nutricional da dieta familiar nas áreas metropolitanas do Brasil (19881996). Rev Saúde Pública 2000; 34:251-8.

7. Instituto Danone. Consumo alimentar: as grandes bases da informação. São Paulo: Instituto Danone; 2000.

8. Schlesselman JJ. Case-control studies: design, conduct, analysis. New York: Oxford University Press; 1982.

9. World Health Organization. Obesity: preventing and managing the global epidemic. Geneva: World Health Organization; 1998.

10. Powers SK, Howley ET. Fisiologia do exercício - teoria e aplicação ao condicionamento e ao desempenho. São Paulo: Editora Manole; 2000.

11. Lima FEL, Fisberg RM, Slater B. Desenvolvimento de um questionário quantitativo de freqüência alimentar (QQFA) para um estudo caso-controle de dieta e câncer de mama em João Pessoa - PB. Rev Bras Epidemiol 2003; 6:373-9.

12. Block G, Coyle LM, Hartman AM, Scoppa SM. Revision of dietary analysis software for the Health Habits and History Questionnaire. Am J Epidemiol 1994; 139:1190-6.

13. Benzecry EH, Pinheiro ABV, Lacerda EMA, Gomes MCS, Costa VM. Tabela para avaliação de consumo alimentar em medidas caseiras. 4a Ed. São Paulo: Editora Atheneu; 2001.

14. Philippi ST. Tabela de composição de alimentos: suporte para decisão nutricional. 2a Ed. São Paulo: Coronário; 2002.

15. Willett WC, Stampfer MJ. Total energy intake: implications for epidemiological analyses. Am J Epidemiol 1986; 124:17-27.

16. Hosmer DW, Lemeshow S. Applied Logistic Regression. New York: John Willey; 1989.

17. Breslow NE, Day NE. Statistical methods in cancer research: the analysis of case-control studies. Lyon: International Agency for Research on Cancer; 1980. (IARC Scientific Publications, 32).

18. Rivera FA, Rivera MAA. Identificação e análise crítica da dieta habitual da população de baixa renda do Estado da Paraíba. Revista do CCS 1984; 6:21-7.

19. Instituto Brasileiro de Geografia e Estatística. Pesquisa de Orçamentos Familiares 2002-2003 - análise da disponibilidade domiciliar de alimentos e do estado nutricional no Brasil. Rio de Janeiro: Instituto Brasileiro de Geografia e Estatística; 2004.
20. Galeazzi MAM, Domene SMA, Sichieri R. Estudo multicêntrico sobre consumo alimentar. Brasília: Ministério da Saúde, Instituto Nacional de Alimentação e Nutrição; 1997. (Cadernos de Debate).

21. Marchioni DML, Fisberg RM, Filho JFG, Kowalski LP, Carvalho MB, Abrahão M et al. Dietary patterns and risk of oral cancer: a case-control study in São Paulo, Brazil. Rev Saude Publica 2007; 41:19-26.

22. Landa MC, Frago N, Tres A. Diet and risk of breast cancer in Spain. Eur J Cancer Prev 1994; 3:313-20.

23. Yuan JM, Wang QS, Ross RK, Henderson BE, Yu MC. Diet and breast cancer in Shanghai and Tijanin, China. Br J Cancer 1995; 71:1353-8.

24. Hirose K, Takezaki T, Hamajima N, Miura S, Tajima K. Dietary factors protective against breast cancer in Japanese premenopausal and postmenopausal women. Int J Cancer 2003; 107:276-82.

25. Gandini S, Merzenich H, Robertson C, Boyle P. Meta-analysis on breast cancer risk and diet: the role of fruit and vegetable consumption and the intake of associated micronutrients. Eur J Cancer 2000; 36:636-46.

26. Riboli E, Norat T. Epidemiologic evidence of the protective effect of fruit and vegetables on cancer risk. Am J Clin Nutr 2003; 78 Suppl:559S-69S.

27. Sauvaget C, Nagano J Hayashi M, Spencer E, Shimizu Y, Allen N. Vegetables and fruit intake and cancer mortality in the Hiroshima/Nagasaki Life Span Study. Br J Cancer 2003; 88:689-94.

28. Mattisson I, Wirfält E, Wallström P, Gullberg B, Olsson H, Berglund G. High fat and alcohol intakes are risk factors of postmenopausal breast cancer: a prospective study from the Malmö diet and cancer cohort. Int J Cancer 2004; 110:589-97.

29. World Cancer Research Fund. Food, nutrition and prevention of cancer: a global perspective. Washington DC: American Institute for Cancer Research; 1997.

30. van Gils CH, Peeters PHM, Bueno-de-Mesquita BB, Boshuizen HC, Lahamann PH, Clavel-Chapelon F, et al. Consumption of vegetables and fruits and risk of breast cancer. JAMA 2005; 293:183-93.

31. Shannon J, Cook LS, Stanford JL. Dietary intake and risk of postmenopausal breast cancer (United States). Cancer Causes Control 2003; 14:19-27.

32. Moorman PG, Terry PD. Consumption of dairy products and the risk of breast cancer: a review of the literature. Am J Clin Nutr 2004; 80:5-14.

33. Shin MH, Holmes MD, Hankinson SE, Wu K, Colditz GA, Willett WC. Intake of dairy products, calcium and vitamin D and risk of breast cancer. J Natl Cancer Inst 2002; 94:1301-11.

34. Potischman N, Coates RJ, Swanson C, Carroll RJ, Daling JR, Brogan DR, et al. Increased risk of early-stage breast cancer related to consumption of sweet foods among women less than 45 in the United States. Cancer Causes Control 2002; 13: 937-46.

35. Ronco AL, De Stefani E, Dátolli R. Dairy foods and risk of breast cancer: a case-control study in Montevideo, Uruguay. Eur J Cancer Prev 2002; 11:457-63. 
36. Cho E, Spiegelman D, Hunter DJ, Chen WY, Stampfer MJ, Colditz GA, et al. Premenopausal fat intake and risk of breast cancer. J Natl Cancer Inst 2003; 1695:1079-85.

37. Pereira RA, Koifman S. Uso do questionário de freqüência na avaliação do consumo alimentar pregresso. Rev Saúde Pública 1999; 33:610-21.

38. Lazcano-Ponce E, Salazar-Martinez E, HernandezÁvila M. Estudios epidemiológicos de casos y controles. Fundamento teórico, variantes y aplicaciones. Salud Publica Mex 2001; 43:135-50.
39. Männistö S, Pietinen P, Virtanen M, Kataja V, Uusitupa M. Diet and risk of breast cancer in a case-control study: does the threat of disease have an influence on recall bias? J Clin Epidemiol 1999; 52:429-39.

40. Block G, Dresser CM, Hartman AM, Carroll MD. Nutrient sources in the American diet: data from the NHANES II survey. 1. Vitamins and minerals. Am J Epidemiol 1986; 122:13-26.

41. Willett WC. Nutritional epidemiology. 2nd Ed. New York: Oxford University Press; 1998.

Submitted on 23/Jan/2007

Final version resubmitted on $03 / \mathrm{Jul} / 2007$

Approved on 24/Aug/2007 